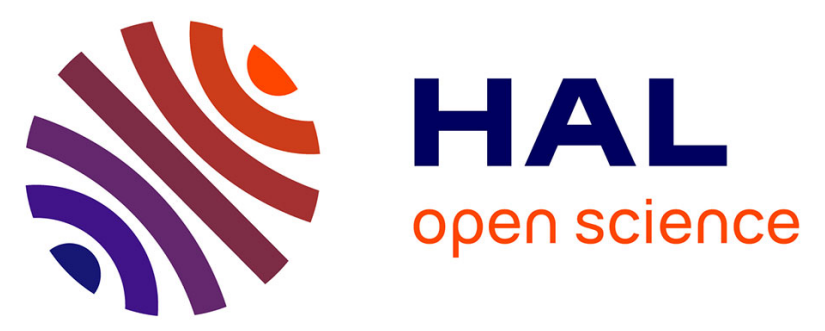

\title{
Pollen rain-vegetation relationship along an elevational gradient in the Serra dos Órgãos National Park, southeastern Brazil
}

Maria Carolina Guarinello de Oliveira Portes, Hugh Deforest Safford, Vincent Montade, Hermann Behling

\section{To cite this version:}

Maria Carolina Guarinello de Oliveira Portes, Hugh Deforest Safford, Vincent Montade, Hermann Behling. Pollen rain-vegetation relationship along an elevational gradient in the Serra dos Órgãos National Park, southeastern Brazil. Review of Palaeobotany and Palynology, 2020, 283, pp.104314. 10.1016/j.revpalbo.2020.104314 . hal-03445400

\author{
HAL Id: hal-03445400 \\ https://hal.science/hal-03445400
}

Submitted on 23 Nov 2021

HAL is a multi-disciplinary open access archive for the deposit and dissemination of scientific research documents, whether they are published or not. The documents may come from teaching and research institutions in France or abroad, or from public or private research centers.
L'archive ouverte pluridisciplinaire HAL, est destinée au dépôt et à la diffusion de documents scientifiques de niveau recherche, publiés ou non, émanant des établissements d'enseignement et de recherche français ou étrangers, des laboratoires publics ou privés. 
Pollen rain-vegetation relationship along an elevational gradient in the Serra dos Órgãos

4 Maria Carolina Guarinello de Oliveira Portes ${ }^{1,2,3}$; Hugh DeForest Safford ${ }^{4,5}$, Vincent

5 Montade $^{1,6}$, Hermann Behling ${ }^{1}$

$6{ }^{1}$ University of Goettingen, Department of Palynology and Climate Dynamics, Albrecht-von-

7 Haller Institute for Plant Sciences, Germany

$8{ }^{2}$ Instituto Chico Mendes de Conservação de Biodiversidade (ICMBio), Brazil

$9{ }^{3}$ CNPq-Brazil Scholarship, Brazil

$10{ }^{4}$ USDA Forest Service, Pacific Southwest Region, Vallejo, California, USA

$11{ }^{5}$ Department of Environmental Science and Policy, University of California, Davis, USA

$12{ }^{6}$ Université de Montpellier, Institut des Sciences de l'Evolution de Montpellier, CNRS, IRD,

13 EPHE, France

15 Abstract We analyzed modern pollen deposition along an altitudinal gradient in the Brazilian

16 southeastern coastal mountains between 1600 and 2200 m elevation in order to investigate

17 the relationship between modern vegetation and pollen rain, within vegetation composed of

18 montane and upper montane forest in a mosaic with campos de altitude (CDA). The results

19 revealed that the CDA pollen assemblage represents a much larger source area than the

20 forest pollen assemblage, which is comprised of more local taxa. Anemophilous pollen from

21 vegetation at lower elevations is overrepresented in the higher elevation pollen traps.

22 Although arboreal taxa dominate the pollen assemblages - even in the grassland pollen

23 traps - the composition of the pollen traps can be confidently related to the vegetation

24 surrounding the collection site. To improve distinction between grassland and forest

25 dominance in a complex environmental mosaic subject to temporal dynamism, we selected

26 a suite of arboreal pollen taxa aiming to reduce the influence of over- and under-

27 representation of some pollen taxa in such kind of environment. Our findings permit more

28 robust interpretation of palaeo-ecological and -geographical relationships between forest

29 and CDA and build a firmer foundation for understanding how future climatic change may

30 impact montane vegetation in SE Brazil.

31 Key words: modern pollen rain, campos de altitude (high elevation grassland), upper

32 montane forest, tropical mountains, tropical South America. 


\section{1. Introduction}

34 The Atlantic Forest biome stretches along Brazil's east coast for more than $4000 \mathrm{~km}$, with the

35 Brazilian Highlands as its geographic backbone. The Atlantic Forest, which once covered as

36 much as 1.3 million $\mathrm{km}^{2}$, has been drastically reduced in area since European settlement in

37 the $16^{\text {th }}$ century (Fundação SOS Mata Atlântica/ INPE, 2017) and is considered one of the

38 world's most threatened biomes as well as one of its most important biodiversity hotspots

39 (Myers et al., 2000). Today, some of the largest remaining fragments of the Atlantic Forest

40 are inside national and state protected areas found on the steep slopes of the Serra do Mar

41 and Serra da Mantiqueira in the states of Rio de Janeiro, Minas Gerais, and São Paulo

42 (Ribeiro et al., 2009). Among the ecosystems covered by these protected areas, some of the

43 most important are upper montane forest and campos de altitude (CDA, or named high

44 elevation grasslands), due to their rarity in eastern Brazil and the high numbers of endemic

45 species they support (Martinelli and Bandeira, 1989; Safford and Martinelli, 2000; Spehn et

46 al., 2010). These ecosystems share the summits of eastern Brazil's highest mountains, with

47 upper montane forest often occupying concavities and protected sites and campos de

48 altitude covering mountaintops and convex slopes (Safford, 1999a). Their geographic

49 relationship is dynamic, with forests dominating in the absence of disturbance and when and

50 where climates are warmer and wetter, and campos dominating after fire and in colder and

51 drier periods (Safford, 1999a, 2001; Portes et al., 2018).

52 Over the last two decades palaeoecological studies based on fossil pollen and charcoal

53 records have been carried out in the southeastern Brazilian highlands in order to better

54 understand past, current, and potential future trends in vegetation, climate, and

55 disturbance, as well as to discern synergies between these factors in driving ecological

56 conditions (e.g. Behling, 1995, 1997a, 1997b, 2007; Scheel-Ybert, 2001; Ledru et al., 2005;

57 Behling et al., 2007; Behling and Safford, 2010; Veríssimo et al., 2012; Raczka et al., 2013;

58 Portes et al., 2018). This work has also provided information important to improve the

59 design of conservation and management strategies that aim for sustainability in the face of

60 rapid global change. However, because pollen production, dispersal, and preservation vary

61 widely among plant species, the relationship between pollen rain, local vegetation and

62 environment is not straightforward, which limits the interpretation of the fossil pollen

63 record (e.g. Prentice, 1988). Studies that relate modern vegetation and environment to

64 pollen rain - especially studies carried out along elevational and ecological gradients - can 
65 help to better discern pollen production and dispersal patterns, as well as habitat and elevational relationships among species and ecological communities in order to improve interpretation of fossil pollen records (e.g. Bartlein et al., 2011; Cárdenas et al., 2014; Jantz 68 et al., 2014; Markgraf et al., 2002; Montade et al., 2016; Niemann et al., 2010; Rodrigues et 69 al., 2016; Schüler et al., 2014; Tonello et al., 2009; Weng et al., 2004).

70 Montade et al. (2019) recently developed the first modern pollen dataset for the full Atlantic 71 Forest biome, describing regional vegetation and climate patterns. Based on this dataset, the 72 authors were able to discern four broad "eco-physiognomies" from modern pollen samples, 73 including northeastern Atlantic rain forest, semi-deciduous and riverine forests, lowland rain 74 forest, and high elevation vegetation consisting of forests and grasslands. In the case of the high elevation vegetation group, the authors pointed out that the fine-spatial scale of 76 intercalation of forest and grassland vegetation posed a challenge to further differentiation that only well-designed, local sampling could resolve. Due to the reduced number of modern pollen samples, several sampling methods had to be combined in this regional dataset.

79 Nonetheless, different sampling methods can present different results which could explain 80 this local scale limitation in differentiating vegetation physiognomies. Surface samples may 81 be considered more representative of the pollen production as pollen rain composition 82 commonly varies over 2 and three 3 as well as according to plant specific systems and changing in climatic conditions (Niemann et al., 2010; Montade et al., 2019). In contrast, pollen traps not only provide the representation and distribution patterns of pollen spectra but also the accumulation rates. Moreover, pollen traps present better pollen preservation, diminishing the difficulty and uncertainties in determination of pollen types and allowing to distinguish similar pollen that normally are classified together, and registering pollen with fragile exine that rarely appear in surface samples or in fossil records (Jantz et al., 2014). The dynamic relationship between CDA and forest is of major ecological, conservation, and management interest in southeastern Brazil (Martinelli and Bandeira 1989; Safford, 1999a;

91 2001; Aximoff 2011; Portes et al., 2018). In order to understand how these ecosystems interact over space and time, we require a robust discrimination of their signal in the fossil pollen record, but to this point such a discrimination had been lacking. To fill this gap, we

94 installed a series of pollen traps along a high elevation transect through areas dominated by 95 montane forest, upper montane forest and CDA in Serra dos Órgãos National Park 96 (PARNASO; Fig. 1). We used pollen traps rather than surface samples so as to better preserve 
97 fragile pollen types that rarely appear in soil surface samples, to diminish identification

98 errors and to allow the calculation of pollen accumulation rates. Our principal purposes were

99 to (1) investigate the relationship between the modern pollen assemblage and local modern

100 vegetation cover; (2) try to better discriminate between grassland and forest dominance in a

101 complex environmental mosaic subject to temporal dynamism; and (3) augment the modern

102 pollen database of the Brazilian Atlantic Forest biome.

103

104 2. Environmental settings

1052.1 Study site

106 Our pollen traps were located along an elevational gradient in the Serra dos Órgãos, a 107 subrange of the Serra do Mar, within PARNASO (Fig. 1). Founded in 1939 as the third 108 national park in Brazil, PARNASO protects 20,024 ha of lower montane, montane and upper 109 montane forest and campos de altitude of the Brazilian Atlantic Forest biome (ICMBio, 110 2008). The park is famous for its spectacular landscape and extraordinary levels of 111 biodiversity. Ironically, it is found in one of the most densely populated areas of Brazil, less 112 than $50 \mathrm{~km}$ from downtown Rio de Janeiro.

113 In the Serra dos Órgãos, basement rocks are mostly Late Proterozoic granite and granitoid 114 gneisses. Topographic relief is associated with late Cenozoic reactivation of faults that 115 originally arose during the opening of the Atlantic Ocean in the late Mesozoic (Machado 116 Filho et al., 1983). Soils in the study area are generally shallow, poorly developed, acidic and

117 highly organic with a deep litter layer (Falkenberg and Voltolini, 1995). As a rule, the Serra 118 dos Órgãos follows a SW-NE orientation parallel to the coastline (Riccomini et al., 1989; 119 Safford, 1999a; ICMBio, 2008).

\section{$121 \quad 2.2 \quad$ Climate}

122 In the broader region, the climate is mostly controlled by the South Atlantic Convergence 123 Zone (SACZ), with most precipitation falling between November and April (Safford, 1999a). 124 Although the climate for the region has been classified as mesothermic with mild and wet 125 summers and moderate winters without a marked dry season (ICMBio, 2008), a winter dry 126 season (months with $<50 \mathrm{~mm}$ precipitation) of two to three months occurs most years in the 127 southeastern Brazilian mountains (Nimer, 1977; Safford, 1999b). The annual average 128 temperature at the nearest long-term meteorological station at Teresópolis $\left(22^{\circ} 25.980^{\prime} S\right.$, 

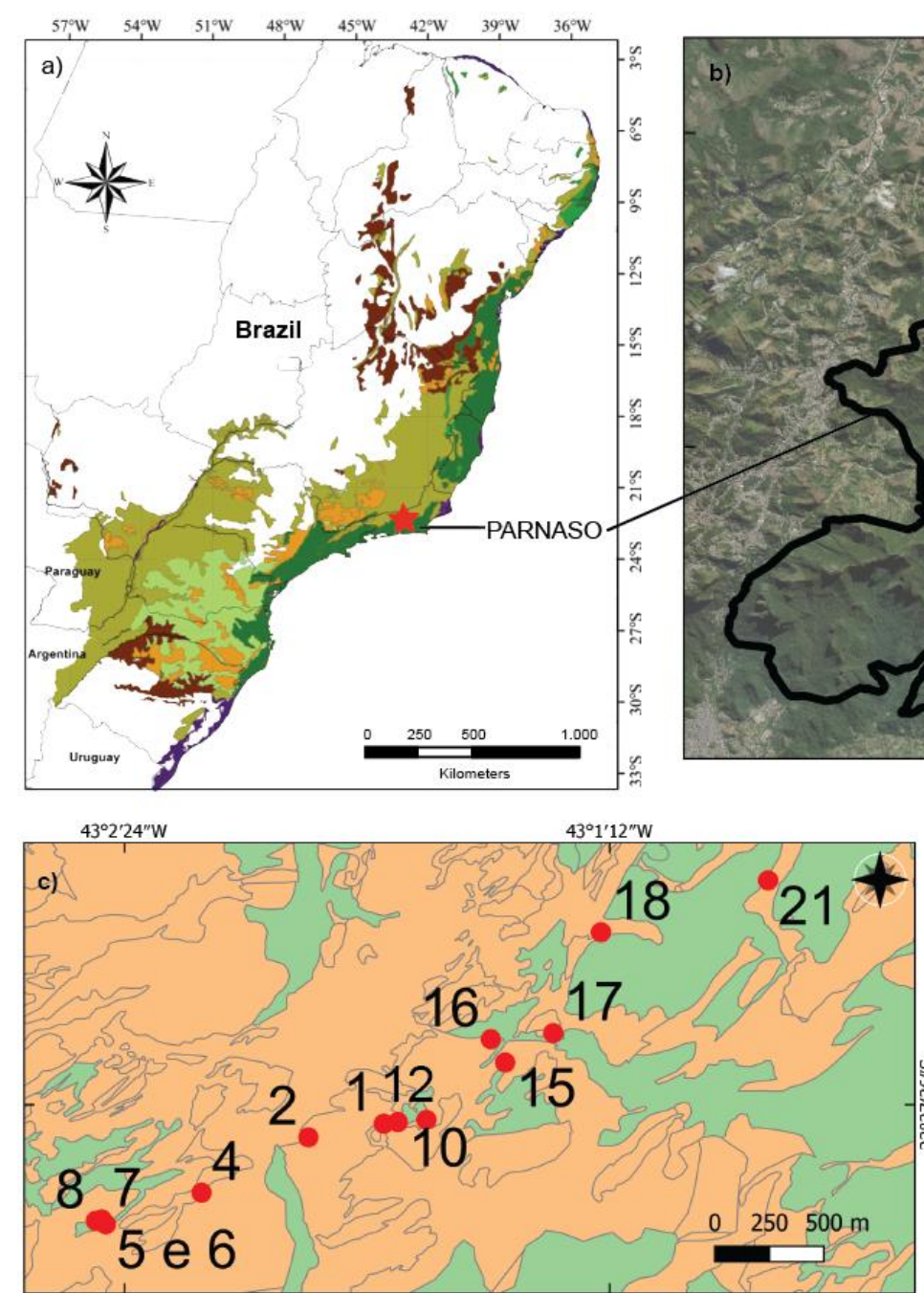

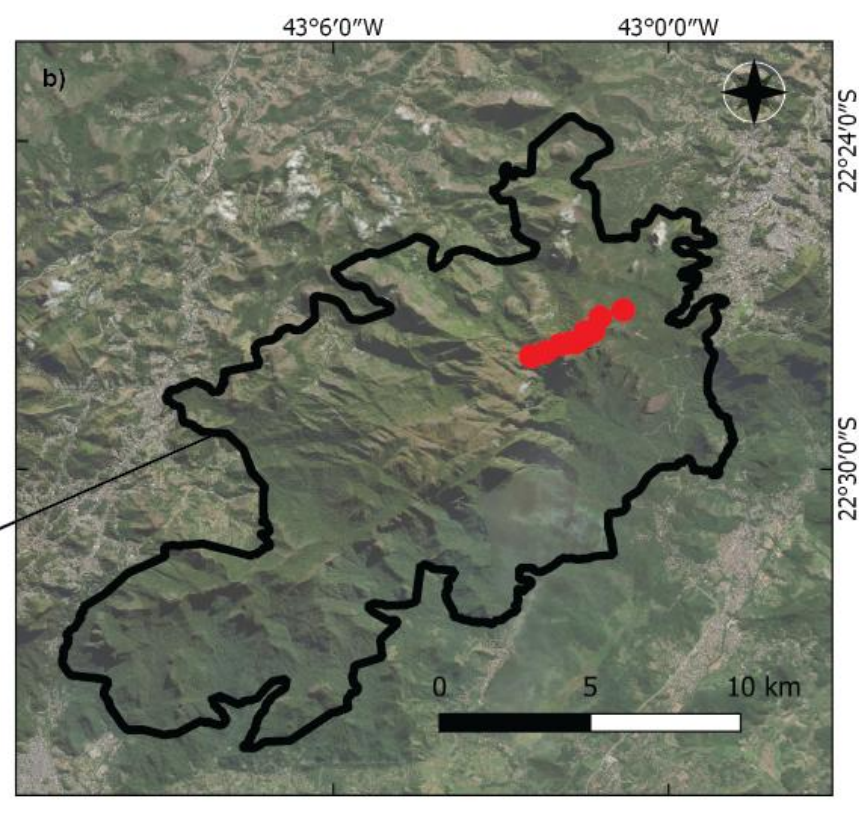

Legend:

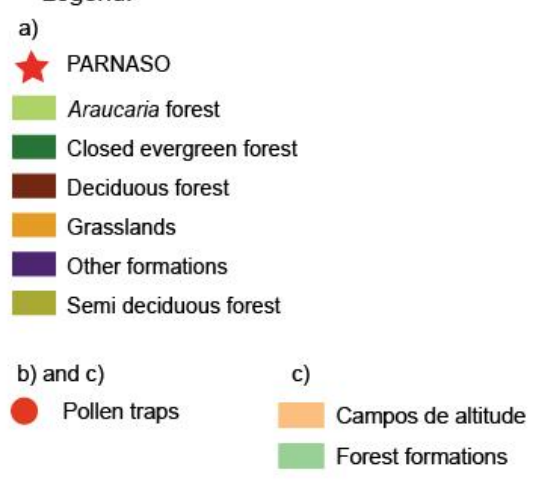

130 Fig. 1. Location of the study site and the pollen traps. a) national location of Parque Nacional 131 da Serra dos Órgãos (PARNASO) (adapted from Fundação SOS Mata Atlântica/ INPE, 2017),

132 b) regional location of PARNASO and c) location of the pollen traps collected in PARNASO.

$13442^{\circ} 58.980 \mathrm{~W}, 1100 \mathrm{~m}$ a.s.l.) is $17.6{ }^{\circ} \mathrm{C}$, ranging from $8.6^{\circ} \mathrm{C}$ (mean of the coldest month 135 July) to $27.2{ }^{\circ} \mathrm{C}$ (mean of the warmest month - February). Mean average precipitation at

136 Teresópolis is $1800 \mathrm{~mm}$, with less than $40 \mathrm{~mm}$ in the driest month (July) and $270 \mathrm{~mm}$ in the

137 wettest (January) (Hijmans et al., 2005). Orographic effects play an important role in 138 modifying the Serra dos Órgãos climate, and elevations higher than Teresópolis are cooler, 139 wetter, and characterized by frequent fog. PARNASO installed temperature data loggers at 140 sites near our transect between September 2012 and February 2014 (C. Cronemberger, 141 PARNASO, pers. comm.). In montane forest at $1600 \mathrm{~m}$ elevation (near pollen trap site 21), 142 the mean overall temperature was $15.4{ }^{\circ} \mathrm{C}$, with an absolute maximum of $30.7{ }^{\circ} \mathrm{C}$ and a 143 minimum of $3.1{ }^{\circ} \mathrm{C}$. In upper montane forest at $2012 \mathrm{~m}$ elevation, mean, maximum and 
144 minimum temperatures were $12.7^{\circ} \mathrm{C}, 25.6{ }^{\circ} \mathrm{C}$, and $1{ }^{\circ} \mathrm{C}$, respectively. Temperatures in the 145 campos de altitude at 1954 m elevation showed a similar mean temperature $\left(12.5^{\circ} \mathrm{C}\right)$, but

146 temperatures were more extreme due to the lack of trees and the valley bottom position: $147 \max =27{ }^{\circ} \mathrm{C}$, $\min =-5.2{ }^{\circ} \mathrm{C}$ ). Safford (unpub. data) measured $-9.8{ }^{\circ} \mathrm{C}$ during a July night in 1481997 at this same campos de altitude site. Safford (1999b) measured soil temperatures from 149 depths of $>75 \mathrm{~cm}$ in deep soil pockets on the summit of Pedra do Sino and obtained an 150 estimate of mean annual temperature of approximately $10.2^{\circ} \mathrm{C}$ at $2260 \mathrm{~m}$ a.s.I.. Annual 151 precipitation in the Serra dos Órgãos at $2000 \mathrm{~m}$ elevation is $>2500 \mathrm{~mm}$ (Safford, 1999b).

\section{$153 \quad 2.3 \quad$ Vegetation}

154 The vegetation encountered at the study sites is classified as montane Atlantic rain forest 155 (ARF), upper montane ARF, and campos de altitude (CDA) (ICMBio, 2008). Montane ARF 156 occurs from c. 700 to c. $1600 \mathrm{~m}$ a.s.l. It typically presents three strata, within the canopy reaching 25-30 m height. Common overstory tree families include Myrtaceae, Lauraceae, Melastomataceae, Fabaceae, Solanaceae, Asteraceae, Rubiaceae, and Euphorbiaceae. Important epiphyte families include Orchidaceae, Bromeliaceae, Gesneriaceae and various ferns. The palm Euterpe edulis, tall Chusquea bamboos, and tree ferns are common in the midstory. Lianas are dominated by Asteraceae, Malpighiaceae, Fabaceae, and Sapindaceae, and shrubs are represented by Rubiaceae, Melastomataceae, Piperaceae, and Begoniaceae, among many other families (Lima and Guedes-Bruni, 1997; Pardo et al., 2007; ICMBio, 2008). Montane habitats grade gradually into upper montane habitats starting above $1300 \mathrm{~m}$ a.s.l., with upper montane ARF prevailing at elevations $>1600 \mathrm{~m}$ a.s.I. (ICMBio, 2008). Due to the common presence of fog, constant winds and other microclimatic conditions, upper montane ARF is characterized by twisted and dwarfed trees and shrubs distributed usually in one stratum $<10 \mathrm{~m}$ height. A salient feature is the abundance and diversity of epiphytes especially Orchidaceae, Bromelicaeae, Cactaceae, ferns and mosses - as a result of the high

170 air humidity (Falkenberg and Voltolini, 1995; Safford, 1999a). The most frequent tree and

171 shrub families are Myrtaceae, Proteaceae, Melastomataceae and Malpighiaceae (ICMBio, 172 2008). Important tree genera include Myrsine, Clethra, Piptocarpha, Myrceugenia, 173 Daphnopsis, Roupala, Weinmannia, Symplocos, Ilex, and Ocotea (Behling and Safford, 2010; 174 Gomes, 2015).

175 CDA vegetation dominates above $1800 \mathrm{~m}$ a.s.l., covering hilltops and convex slopes as well as 
176 poorly-drained valley bottoms that are affected by cold air drainage (Safford, 1999a; ICMBio,

177 2008). The CDA is dominated by tall bunchgrasses and sedges (especially Cortaderia and

178 Machaerina), montane bamboo (Chusquea) and a heterogeneous mixture of sclerophyllous

179 shrubs, particularly from the genera Baccharis and Escallonia, and the families Asteraceae,

180 Ericaceae, Melastomataceae, and Myrtaceae. Frequent herbs are Eryngium, Paepalanthus,

181 Plantago and Xyris, and lycopods and cool-weather bryophytes are widespread (Behling and

182 Safford, 2010).

184 3. Material and Methods

\section{$185 \quad 3.1 \quad$ Pollen trap design and sampling}

186 For collection of the modern pollen assemblage of the mountain vegetation of PARNASO, 23

187 pollen traps were placed along a 4-km section of the Pedra do Sino trail, ranging from 1600 $188 \mathrm{~m}$ to $2200 \mathrm{~m}$ a.s.l., between the coordinates $22^{\circ} 26^{\prime} 53^{\prime \prime} \mathrm{S}, 43^{\circ} 00^{\prime} 28^{\prime \prime} \mathrm{W}$ and $22^{\circ} 27^{\prime} 53^{\prime \prime} \mathrm{S}$, $18943^{\circ} 02^{\prime} 28^{\prime \prime} \mathrm{W}$ (Fig. 1). Each pollen trap was classified according to their respective local 190 vegetation in the field (CDA, upper montane ARF and montane ARF). The trap model used 191 was developed by Behling and formally described in Behling et al. (2001) and tested by Jantz 192 et al. (2013). Each trap was installed about $10 \mathrm{~cm}$ above the soil surface in October, 2015 193 and collected in October, 2016 (Table 1).

\section{$195 \quad 3.2 \quad$ Pollen analysis}

196 The pollen grains were extracted from each trap as described in Jantz et al. (2013). Before 197 processing, one tablet of Lycopodium clavatum spores $(20,848$ ?]1546, batch 3862) was 198 added as exotic marker to each sample for influx calculation. Acetolysis was carried out to 199 dissolve cellulose material and to stain the pollen residues. The pollen residue obtained was 200 kept in distilled water until mounted in slides with glycerine for pollen analysis. Samples 201 were counted to a minimum of 300 pollen grains and identification of pollen and spores was 202 based on the reference collection of Brazil and Ecuador at the Department of Palynology and 203 Climate Dynamics, University of Goettingen (Germany). Further support was obtained from 204 literature and electronic pollen keys (Behling, 1993; Melhem et al., 2003; Bush and Weng, 205 2006; Neotropical Fossil Pollen Search Tool developed by Dr. Hermann Behling and Dr. 206 Chengyu Weng, unpublished). Nomenclature follows the Flora do Brasil 2020 207 (http://floradobrasil.jbjr.gov.br). Pollen percentages were calculated excluding aquatics, 
208 exotics, unidentified and spores. Pollen diagrams were plotted using the C2 software 209 (Juggins, 2007) and clustered according to the habit and the ecology of the taxa.

211 Table 1. List of 23 pollen traps grouped by vegetation zone where each trap was installed, 212 with their geographic coordinates and elevation. In black the recovered traps and in gray the 213 unfounded ones.

\begin{tabular}{|c|c|c|c|c|}
\hline Vegetation & Sample & Coordinate S & Coordinate W & Altitude $(\mathrm{m})$ \\
\hline \multirow{9}{*}{$\begin{array}{l}\text { Campos de altitude } \\
\text { (CDA) }\end{array}$} & SOPT1 & $22^{\circ} 27^{\prime} 38.48^{\prime \prime}$ & $43^{\circ} 01^{\prime} 45.66^{\prime \prime}$ & 2188 \\
\hline & SOPT10 & $22^{\circ} 27^{\prime} 38.23^{\prime \prime}$ & $43^{\circ} 01^{\prime} 43.57^{\prime \prime}$ & 2180 \\
\hline & SOPT2 & $22^{\circ} 27^{\prime} 40.50^{\prime \prime}$ & $43^{\circ} 01^{\prime} 56.86^{\prime \prime}$ & 2169 \\
\hline & SOPT11 & $22^{\circ} 27^{\prime} 37.87^{\prime \prime}$ & $43^{\circ} 01^{\prime} 36.44^{\prime \prime}$ & 2148 \\
\hline & SOPT15 & $22^{\circ} 27^{\prime} 29.41^{\prime \prime}$ & $43^{\circ} 01^{\prime} 27.66^{\prime \prime}$ & 2128 \\
\hline & SOPT13 & $22^{\circ} 27^{\prime} 33.08^{\prime \prime}$ & $43^{\circ} 01^{\prime} 43.46^{\prime \prime}$ & 2126 \\
\hline & SOPT14 & $22^{\circ} 27^{\prime} 31.78^{\prime \prime}$ & $43^{\circ} 01^{\prime} 40.81^{\prime \prime}$ & 2115 \\
\hline & SOPT3 & $22^{\circ} 27^{\prime} 44.86^{\prime \prime}$ & $43^{\circ} 02^{\prime} 4.27^{\prime \prime}$ & 2107 \\
\hline & SOPT4 & $22^{\circ} 27^{\prime} 48.70^{\prime \prime}$ & $43^{\circ} 02^{\prime} 12.70^{\prime \prime}$ & 2086 \\
\hline \multirow{9}{*}{ Upper montane ARF } & SOPT16 & $22^{\circ} 27^{\prime} 25.96^{\prime \prime}$ & $43^{\circ} 01^{\prime} 29.78^{\prime \prime}$ & 2157 \\
\hline & SOPT12 & $22^{\circ} 27^{\prime} 37.90^{\prime \prime}$ & $43^{\circ} 01^{\prime} 39.36^{\prime \prime}$ & 2134 \\
\hline & SOPT9 & $22^{\circ} 27^{\prime} 46.30^{\prime \prime}$ & $43^{\circ} 02^{\prime} 6.97^{\prime \prime}$ & 2113 \\
\hline & SOPT17 & $22^{\circ} 27^{\prime} 25.06^{\prime \prime}$ & $43^{\circ} 01^{\prime} 20.53^{\prime \prime}$ & 2031 \\
\hline & SOPT7 & $22^{\circ} 27^{\prime} 52.67^{\prime \prime}$ & $43^{\circ} 02^{\prime} 27.52^{\prime \prime}$ & 2013 \\
\hline & SOPT8 & $22^{\circ} 27^{\prime} 52.88^{\prime \prime}$ & $43^{\circ} 02^{\prime} 28.39^{\prime \prime}$ & 2008 \\
\hline & SOPT5 & $22^{\circ} 27^{\prime} 53.40^{\prime \prime}$ & $43^{\circ} 02^{\prime} 26.91^{\prime \prime}$ & 2003 \\
\hline & SOPT6 & $22^{\circ} 27^{\prime} 53.40^{\prime \prime}$ & $43^{\circ} 02^{\prime} 26.91^{\prime \prime}$ & 2003 \\
\hline & SOPT18 & $22^{\circ} 27^{\prime} 10.12^{\prime \prime}$ & $43^{\circ} 01^{\prime} 13.44^{\prime \prime}$ & 1923 \\
\hline \multirow{5}{*}{ Montane ARF } & SOPT19 & $22^{\circ} 27^{\prime} 18.18^{\prime \prime}$ & $43^{\circ} 01^{\prime} 3.40^{\prime \prime}$ & 1844 \\
\hline & SOPT20 & $22^{\circ} 27^{\prime} 8.17^{\prime \prime}$ & $43^{\circ} 0^{\prime} 53.60^{\prime \prime}$ & 1671 \\
\hline & SOPT21 & $22^{\circ} 27^{\prime} 02.41^{\prime \prime}$ & $43^{\circ} 00^{\prime} 48.67^{\prime \prime}$ & 1597 \\
\hline & SOPT22 & $22^{\circ} 26^{\prime} 54.49^{\prime \prime}$ & $43^{\circ} 00^{\prime} 49.36^{\prime \prime}$ & 1439 \\
\hline & SOPT23 & $22^{\circ} 26^{\prime} 53.27^{\prime \prime}$ & $43^{\circ} 00^{\prime} 28.15^{\prime \prime}$ & 1287 \\
\hline
\end{tabular}

\section{$215 \quad 3.3 \quad$ Vegetation cover analysis and multivariate analysis}

216 The modern vegetation surrounding each pollen trap was analyzed using the software QGIS

217 (QGIS Developing Team, 2019) based on a Bing aerial image (2019) with support of 218 geographical information from 2008 provided by PARNASO. We delimited buffers of 0.79 ha 219 (50 $\mathrm{m}$ radius), 3.14 ha (100 $\mathrm{m}$ radius), and 78.6 ha (500 $\mathrm{m}$ radius) for each trap (see 220 supplementary material) and identified the percentage of the area dominated by two 221 different components: forest and CDA. The CDA component includes CDA sensu stricto, rock 
222 vegetation, and rock outcrops. A coefficient of correlation ( $r$ ) was calculated between

223 percentage values of vegetation cover and pollen data for the forest and CDA components

224 within each of the buffer areas.

225 A correspondence analysis (CA) was applied with R-packages ADE4 (Dray and Dufour, 2007)

226 and VEGAN (Orkansen et al., 2019) in R-Studio (R-Studio Team, 2016) to investigate

227 correlations between pollen spectra from the pollen traps and the representative

228 vegetation. We focused on the CDA and upper montane forest groups and excluded the

229 montane forest group from the CA as it was characterized by only one sample (SOPT21). In

230 order to reduce noise, the CA was performed with the major pollen taxa (with percentages

231 ? $1 \%$ occurring in at least three samples). Percentage values were square-root transformed

232 before performing the CA to stabilize the variance.

233 To better reconstruct the local changes of ARF in this mosaic of grassland and forest, we

234 defined a group of most distinctive pollen taxa of upper montane ARF composed by 235 Weinmannia, Myrsine, Clethra, and Myrtaceae based on the results of the CA and 236 considering pollen assemblages, habit and ecological features. We also considered the

237 facility in distinguishing these taxa (important when comparing several sites involving

238 different palynologists) as well as their abundance and well preservation in fossil samples.

239 This restricted group of ARF and the ARF group were passively projected on the first and 240 second axes of the CA bi-plot.

242 4. Results

2434.1 Modern pollen rain

244 Of the original 23 pollen traps only 14 were recovered. A total of 98 pollen types and 24 245 spores were identified from the recovered traps. The most abundant and important taxa are 246 displayed in the pollen diagrams (Figs. 2 and 3). A list of all palynomorphs identified can be 247 found in the supplementary material. The pollen taxa were classified into the following 248 ecological groups based on their habit and ecology: CDA including subgroups herbs and 249 shrubs and Asteraceae; upper montane ARF; montane ARF; sub-aquatics, exotics, tree ferns, 250 and ferns. The separation of the groups follows Safford (1999a), Behling and Safford (2010), 251 Gomes (2015) and Montade et al. (2019).

252 According to their respective local vegetation and elevation, the pollen sampling sites were 253 separated into three ecological zones: CDA, upper montane ARF, and montane ARF (Table 1). 
254 Each zone is typified by a characteristic pollen assemblage composition and abundance.

255 Overall, arboreal taxa predominate in the pollen rain, even in samples taken from CDA

256 vegetation. The five most abundant taxa in all pollen spectra are Myrsine, Melastomataceae,

257 Poaceae, Moraceae/Urticaceae, and Weinmannia. Asteraceae, Myrtaceae, Cecropia, and

258 Alchornea were present in all samples, along with the introduced taxon Pinus.

$260 \quad 4.1 .1$ Campos de altitude (5 samples)

261 Although this vegetation zone is characterized principally by herbs, shrubs, and Asteraceae,

262 forest pollen types are up to $65 \%$ of all pollen; that is, pollen from the CDA ecological group 263 only contributed an average of $35 \%$ of the pollen collected in the traps. In this vegetation 264 type, pollen of Poaceae (16\%) and Baccharis (c.10\%, separated from other Asteraceae pollen 265 types due to its relatively high number of small and long echini (Behling, 1993)) are the best 266 indicators. Pollen taxa of upper montane ARF (Myrsine > 10\%, Weinmannia c. 4\% and Clethra 267 1\%) and montane ARF (Moraceae/Urticaceae c. 12\%, Melastomataceae c. 10\%, Cecropia 5\%, 268 Celtis c. 3\%, Myrtaceae 2\%, and Alchornea c. 2\%) are also abundant. There is high variability 269 among samples for some pollen taxa. For example, Baccharis represents c. $34 \%$ and 270 Melastomataceae c. $20 \%$ in sample SOPT1 and Cyperaceae almost $12 \%$ in SOPT2. Although 271 Eryngium type 2 is generally rare, it occurs at a high percentage in a single sample (SOPT10 > 272 9\%). Mimosa scabrella reaches c. 3\% in SOPT2 with average of c. 1\% in this zone. Spores of 273 tree ferns are almost absent in CDA, the average sum of other spores reaches $3 \%$ while the 274 exotic Pinus is about $1 \%$ in this zone.

275 Pollen influx is very low in traps in CDA, the mean value is $<2000$ pollen grains $\mathrm{cm}^{-2}$, varying 276 from 920 to 3055 pollen grains $\mathrm{cm}^{-2}$. In the CDA zone, the sum of characteristic CDA taxa 277 produces an average influx of c. 700 pollen grains $\mathrm{cm}^{-2}$, while upper montane ARF average 278 influx is 335 pollen grains $\mathrm{cm}^{-2}$ and the montane ARF average is 945 pollen grain $\mathrm{cm}^{-2}$.

280 4.1.2 Upper montane ARF (8 samples) and montane ARF (1 sample)

281 Upper montane vegetation is well represented by its pollen assemblage. The upper 282 montane/montane ARF zone (they are combined here due to similar pollen spectra and the 283 existence of only one sample in the montane ARF zone) is characterized by higher spore 284 sums than the CDA zone. Myrsine, Weinmannia, Lauraceae, Griselinia, and Clethra are the 285 most important upper montane ARF indicator taxa with averages of $c .18 \%, 7 \%, 4 \%, 2 \%$, and 


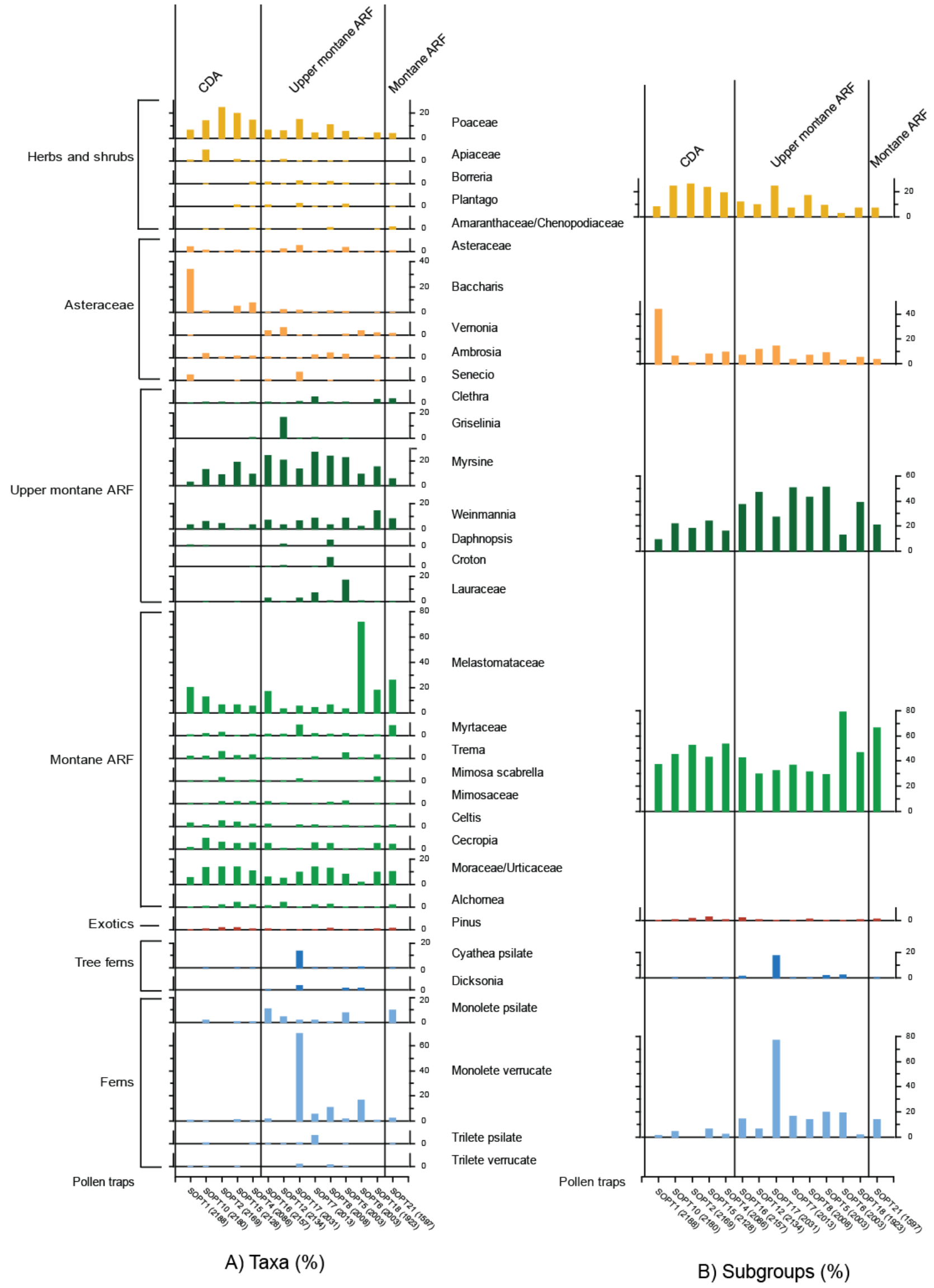

Fig. 2. Percentage diagram of main taxa per groups sorted by vegetation types and altitude. 
290 respectively. The main montane ARF pollen taxa are Melastomataceae 18\%,

291 Moraceae/Urticaceae 9\%, Cecropia c. 3\% and Myrtaceae 3\%. Pollen traps from SOPT17 and 292 SOPT18 have higher values of Mimosa scabrella, $2 \%$ and $4 \%$ respectively, and

293 Melastomataceae represents $72 \%$ of all pollen in the trap SOPT6. Pollen types from the CDA

294 ecological group contribute about $19 \%$ of all pollen in the ARF zone, mainly from Poaceae (c.

295 7\%), Vernonia (c. 2\%), and other Asteraceae types (c. 2\%). Two outlying samples are SOPT6

296 (7\% CDA pollen) and SOPT17 (c. 40\% CDA pollen). The average for tree ferns reaches c. 3\%,

297 but SOPT17 shows very high values: Cyathea with 14\% and Dicksonia with c. 4\%. The group

298 of sub-aquatic taxa is represented by c. $2 \%$ and exotics by c. $1 \%$ pollen.

299 Regarding pollen influx in these zones, the average sum is 10,400 pollen grains $\mathrm{cm}^{-2}$, varying 300 from 5000 in SOPT17 to 20,000 in SOPT21. The influx of taxa from the upper montane ARF 301 ecological group ranges from 1400 to 6250 pollen grains $\mathrm{cm}^{-2}$ and taxa correlated with the 302 montane ARF ecological group range from 1700 to 13000 pollen grains $\mathrm{cm}^{-2}$. Pollen influx 303 from the CDA ecological group averages 1700 pollen grains $\mathrm{cm}^{-2}$.

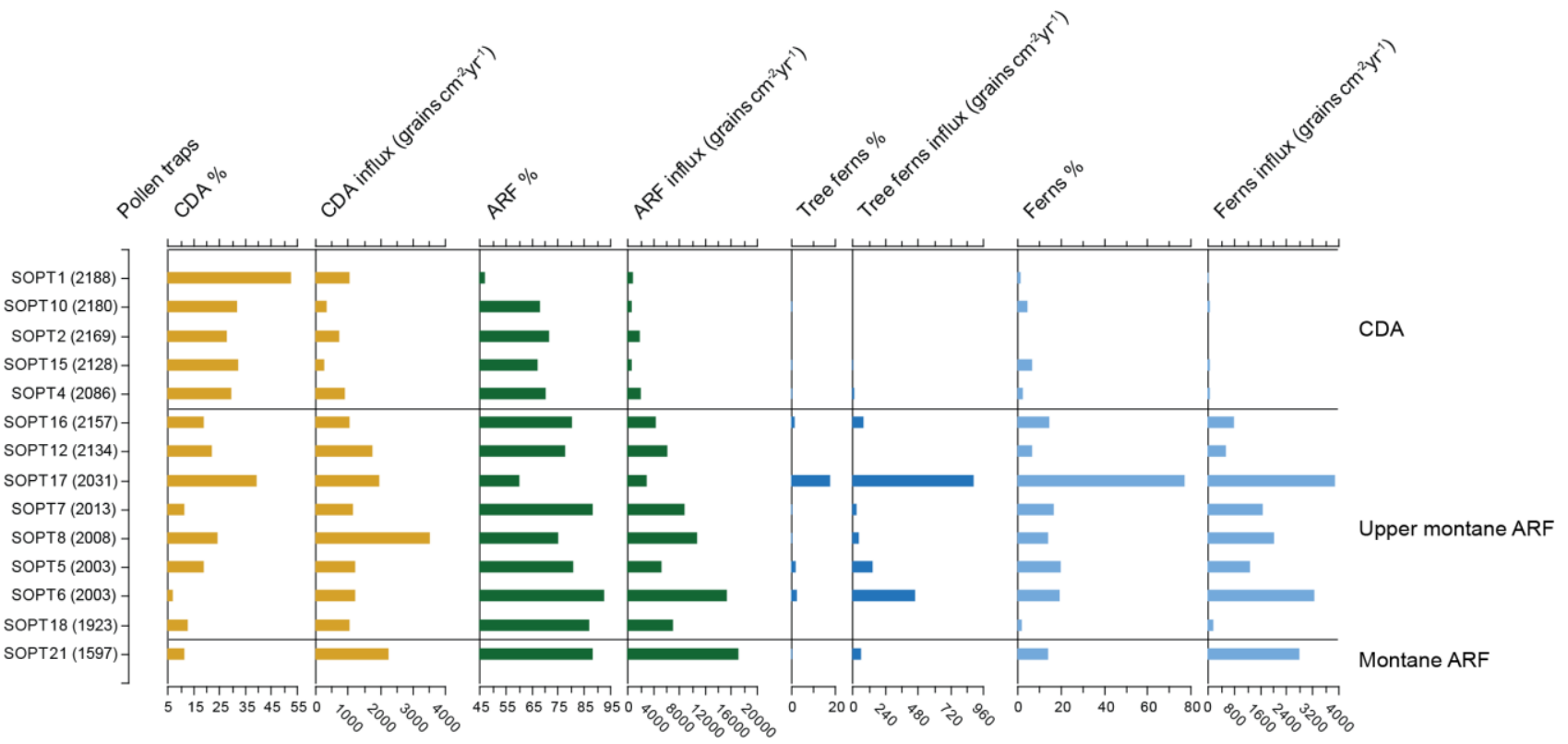

306 Fig. 3. Percentage and influx diagram of groups sorted by vegetation types and altitude.

$308 \quad 4.2 \quad$ Vegetation cover and multivariate analysis

309 Table 2 shows the percentage of CDA and forest vegetation surrounding each pollen trap 310 using spatial buffers of $50 \mathrm{~m}$ radius ( 0.79 ha total area), $100 \mathrm{~m}$ radius ( $3.14 \mathrm{ha}$ ) and $500 \mathrm{~m}$ 
311 (78.6 ha) radius, combined with pollen percentage of the CDA and ARF ecological groups.

312 Applying a smaller buffer would have been interesting if the satellite image presented higher

313 resolution however, with the resolution available, the surrounded vegetation was the same

314 as in the pollen traps classification. Pollen traps installed in CDA are mostly surrounded by

315 CDA vegetation (mean $=>70 \%$ CDA vegetation) in all sizes of buffer, although the percentage

316 of forest vegetation is higher at the $500 \mathrm{~m}$ radius. With buffer at $50 \mathrm{~m}$, the highest \% of

317 forest is shown in SOPT10 (c. 30\%) and with buffer at $100 \mathrm{~m}$ both SOPT10 and SOPT15 reach

318 c. $16 \%$. On the other hand, the area surrounding the pollen traps in upper montane forest

319 only averaged $55 \%$ of forest in the small buffer (excluding SOPT 21 ) and $<70 \%$ in the two

320 larger buffers. The one recovered trap installed in montane forest (SOPT21) at lower altitude

321 is dominated by forest vegetation at all buffer sizes, although the 78.6 ha buffer included a

322 number of patches of open canopy where rock and herbaceous vegetation dominated. The

323 correlation coefficient $(r)$ between the pollen assemblages and the respective vegetation

324 groups dropped as buffer size increased. The coefficients for the CDA group are 0.63 for 50

$325 \mathrm{~m}$ radius, 0.48 for $100 \mathrm{~m}$ and 0.36 for $500 \mathrm{~m}$ radius, while in the ARF group the coefficients

326 are $0.60,0.49$, and 0.39 for 50,100 , and 500 m radius, respectively (Fig. 4).

327 A preliminary correspondence analysis using 13 samples clearly separated a group that 328 includes all samples from SOPT6 (supplementary material). This sample is characterized by a

329 high value of Melastomataceae $(>70 \%)$ due to a local signal. We therefore considered this

330 sample as an outlier and performed a new CA with 12 samples to provide an understanding

331 of the relationships among pollen assemblages and vegetation groups (Fig. 5). The first two

332 axes explain $54.6 \%$ of the total variation. Axis 1 clearly separates CDA from forest pollen trap

333 samples (Fig. 5a). The most robust CDA indicators include Baccharis (displaced upward along

334 ordination Axis 2 by its strong association with sample SOPT1), Melastomataceae, and

335 Poaceae, as well the woody genera (trees and lianas) Celtis, Trema, and Cecropia, all of

336 which are pioneer taxa in disturbed forest (Fig. 5b). Mimosaceae, Alchornea, and

337 Moraceae/Urticaceae (also largely pioneer/secondary taxa) are located very close to the Axis

3381 origin line and are not very robust indicators of CDA sites as they occur in all vegetation

339 groups (see Fig. 2). Indicators of forest habitats have a stronger signal in the ordination. The

340 most robust forest indicators according to the results of the CA are Lauraceae, Vernonia,

341 Plantago and Borreria (excluding Lauraceae, they are weedy, mostly herbaceous genera,

342 Plantago is cosmopolitan and Vernonia and Borreria are found mostly in warm, tropical 
343 habitats), followed by the upper montane forest taxa Myrsine, Clethra, Weinmannia, and 344 Myrtaceae (Fig. 5b).

345 To present an assemblage approach whereby associations of pollen taxa are better 346 indicative of a particular vegetation type, we defined a restricted group representing the 347 ARF. For this restricted group of forest habitat, we considered several aspects to select the 348 taxa. We only considered arboreal pollen taxa. Although evidenced as robust indicators based on the CA (Fig. 5b), we for example excluded Plantago, Vernonia, and Borreria which represent mostly herbaceous genera and which can also be characteristic of CDA. Among the arboreal pollen taxa, we excluded taxa which are abundant in CDA pollen traps, e.g. Celtis, Alchornea, Trema, Cecropia, Mimosaceae, Moraceae/Urticaceae (Fig. 2 and 5b). Their high relative abundances in CDA pollen traps is certainly due to high pollen productivity of these taxa (Gosling et al., 2009; Jantz et al., 2013; Schüler et al., 2014) and their occurrence as dwarfed trees in or near CDA habitats. The representativeness of the taxa in fossil records was also considered for the selection of taxa. For example, although Lauraceae is one of the best indicators of forest in modern pollen rain (Fig. 2 and 5b), this pollen taxon is generally not well preserved in the fossil pollen records due to its thin exine (Behling, 1993) and it was excluded from the restricted forest group. We finally settled our choice on Weinmannia, Myrsine, Clethra, and Myrtaceae, which are good indicators of upper montane ARF since they are morphologically distinct arboreal pollen taxa and easily distinguished, they are significantly more abundant in upper montane forest than in CDA (Figures 2 and 5b) and

363 they are generally well preserved and abundant in fossil pollen records (Behling, 1997a; 364 Behling et al., 2007; Behling and Safford, 2010; Niemann et al., 2010; Veríssimo et al., 2012). 365 The correlation between the restricted ARF group and the forest vegetation cover at $50 \mathrm{~m}(\mathrm{r}$ $366=0.74)$ shows a higher correlation than the correlation calculated between the ARF group and forest vegetation cover at $50 \mathrm{~m}(r=0.55)$ in figure $5 c$. We also try to select taxa to better

368 discriminate CDA, however this was discarded because this group is mostly composed of 369 Poaceae which pollen grains are extremely difficult to be identified to species or genera level 370 due to the rather uniform morphology, and may be over-represented in some fossil records 371 according to the study site (e.g. Gosling et al., 2009). 



Pollen (\%)

374 Fig. 4. Correlation coefficient ( $r$ ) between pollen group and modern vegetation for spatial 375 buffers of 50,100 and $500 \mathrm{~m}$ radius. Pollen traps of CDA are in orange and ARF in green. 

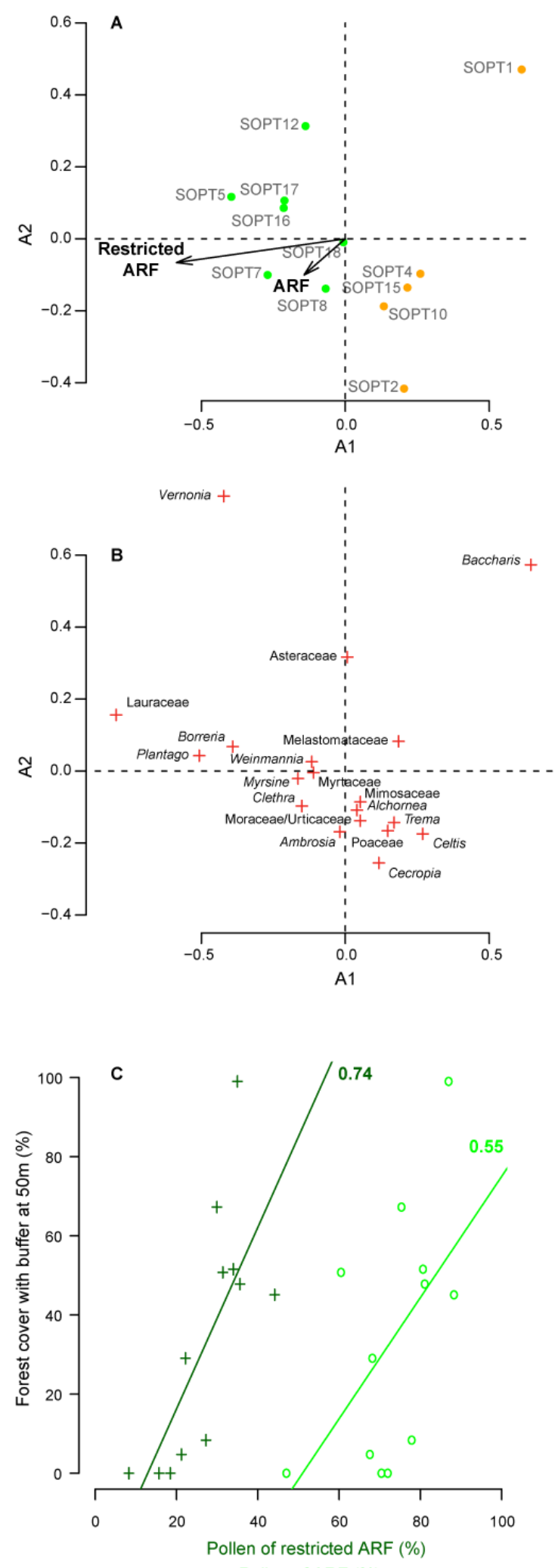

377 Fig. 5. Correspondence Analysis (CA) for axes 1 and 2 using pollen taxa $\geq 1 \%$ in at least three 378 samples. A - distribution of pollen traps (CDA in orange and ARF in green) with the projection 379 of the ARF restricted group and ARF group, B - distribution of pollen taxa, C -correlation 380 between ARF restricted group and forest vegetation cover with buffer at $50 \mathrm{~m}$ (dark green) 381 and correlation between ARF and forest vegetation cover with buffer at $50 \mathrm{~m}$ (light green). 
382 Table 2. Percentages of total vegetation cover comprised by campos (CDA) and forest (ARF)

383 vegetation within areas of 0.79 ha (50 m radius), 3.14 ha (100 m radius) and 78.6 ha (500 m

384 radius) surrounding each pollen trap, and pollen \% of CDA group and ARF group in each

385 pollen trap. Table organized by vegetation type found at the pollen trap site.

\begin{tabular}{|c|c|c|c|c|c|c|c|c|}
\hline \multirow[t]{2}{*}{ Sample } & \multicolumn{2}{|c|}{ Buffer 50 m } & \multicolumn{2}{|c|}{ Buffer 100 m } & \multicolumn{2}{|c|}{ Buffer $500 \mathrm{~m}$} & \multicolumn{2}{|l|}{ Pollen } \\
\hline & Campos & Forest & Campos & Forest & Campos & Forest & CDA & ARF \\
\hline CDA (mean) & 93.2 & 6.8 & 93.2 & 6.8 & 80.8 & 16.07 & 34.98 & 65.02 \\
\hline SOPT1 & 100.00 & 0.00 & 97.89 & 1.97 & 81.61 & 14.85 & 52.98 & 47.02 \\
\hline SOPT10 & 70.95 & 29.05 & 84.29 & 15.60 & 81.20 & 15.39 & 31.83 & 68.17 \\
\hline SOPT2 & 100.00 & 0.00 & 99.90 & 0.00 & 84.29 & 12.29 & 28.04 & 71.96 \\
\hline SOPT15 & 95.26 & 4.74 & 83.93 & 16.17 & 78.30 & 22.60 & 32.45 & 67.55 \\
\hline SOPT4 & 100.00 & 0.00 & 100.08 & 0.00 & 78.66 & 15.19 & 29.59 & 70.41 \\
\hline ARF (mean) & 40.6 & 59.4 & 63.8 & 36.2 & 66.0 & 34.0 & 18.73 & 81.27 \\
\hline SOPT16 & 48.44 & 51.56 & 44.93 & 55.08 & 72.62 & 29.38 & 19.38 & 80.63 \\
\hline SOPT12 & 74.60 & 25.40 & 75.95 & 24.03 & 77.87 & 16.07 & 22.16 & 77.84 \\
\hline SOPT17 & 49.25 & 50.75 & 71.61 & 28.28 & 64.01 & 38.44 & 39.54 & 60.46 \\
\hline SOPT7 & 54.91 & 45.09 & 79.26 & 20.78 & 78.90 & 21.04 & 11.75 & 88.25 \\
\hline SOPT8 & 32.75 & 67.25 & 77.67 & 22.40 & 79.08 & 20.79 & 24.67 & 75.33 \\
\hline SOPT5 & 52.20 & 47.80 & 79.87 & 20.06 & 79.48 & 20.46 & 18.95 & 81.05 \\
\hline SOPT6 & 52.20 & 47.80 & 79.87 & 20.06 & 79.48 & 20.46 & 7.36 & 92.64 \\
\hline SOPT18 & 0.99 & 99.01 & 64.79 & 35.37 & 45.06 & 57.50 & 13.07 & 86.93 \\
\hline SOPT21 & 0.00 & 100.00 & 0.40 & 99.60 & 18.36 & 81.66 & 11.68 & 88.32 \\
\hline
\end{tabular}

387 5. Interpretation and discussion

388 The pollen rain collected by our traps permitted a relatively robust discrimination of campos

389 de altitude (CDA) and upper montane forest (ARF) habitats, even though there was notable

390 overlap between the pollen assemblages. With respect to the CDA, our pollen trap data

391 show that the pollen taxa most indicative of the CDA environment are Poaceae and

392 Baccharis. Other common taxa in the CDA pollen traps represent (mostly small tree/shrub)

393 taxa shared with ARF, or pioneer or secondary tree/liana taxa associated with disturbed

394 forest habitats at lower elevations. The upper montane ARF pollen traps were characterized

395 by a suite of taxa that are common to all eastern and southern Brazilian studies of mountain

396 forests (e.g. Portes et al., 2001; Koehler et al., 2002; Sheer and Mocochinski, 2009; Gomes;

397 2015). These include, most prominently, Melastomataceae, Myrsine, and Weinmannia, but

398 also Clethra, Symplocos, Drimys, Croton, Myrtaceae, Ilex, and the tree ferns Cyathea and

399 Dicksonia. In addition, as pollen traps allow better pollen preservation than surface samples,

400 we recorded a high percentage of Lauraceae, which, although very characteristic of upper

401 montane ARF, have thin exine therefore are not commonly found in fossil pollen records

402 (see also Cardenás et al., 2019). 
403 These results are strikingly similar to those of Montade et al. (2019), who carried out a broad

404 geographic meta-analysis of 125 modern pollen samples across the Atlantic Forest biome.

405 Montade et al. (2019) also found high levels of pollen taxa overlap between neighboring 406 high elevation vegetation types, including campos de altitude, Araucaria forest, and upper 407 montane Atlantic Forest. They ascribed at least some of this palynological concordance to 408 the mosaic pattern of habitats that characterizes the higher Brazilian mountains (Safford, 409 1999a), where patches of grassland and forests occur in such close proximity that typical 410 pollen sampling methods cannot discern a completely "clean" pollen signature from either 411 habitat. We found the same pattern of pollen "pollution" happening between our CDA and 412 ARF traps. This was especially pronounced in the CDA traps, where upper montane ARF taxa 413 comprised almost $2 / 3$ of the captured pollen. This was due to at least three factors. First, the 414 Brazilian Highlands do not reach the elevations of climatic treeline (Safford, 1999b), 415 therefore the presence and distribution of high-elevation páramo-like grasslands is driven by 416 local-scale environmental and disturbance gradients that lead to a very fine-grained 417 intercalation of grassland and forest patches (Safford, 1999a, 2001). Second, many taxa from 418 the upper montane ARF - such as the prodigious pollen producers Myrsine and Weinmannia, 419 as well as various species of Myrtaceae, Melastomataceae, Croton, Drimys, Clethra, and 420 Symplocos - occur as shrubs or small scattered trees in the campos de altitude (Safford, 421 2007). These are usually interpreted as either remnants of burned forest stands, or pioneers 422 of forest expansion. Third, CDA vegetation is characterized by a much lower pollen 423 production and accumulation rate than the montane or upper montane ARF. The same 424 pattern was recognized by Bush (2000) in a study of páramo vs treeline forests in Central 425 America and by Gosling at al. (2009) in an ecotonal area of tropical forest, semi-deciduous 426 forest and savannah in Colombia. Even though Poaceae is wind-pollinated, most of the 427 genera in the CDA require a pollen vector (c. $71 \%$ are insect-pollinated and 5\% bird or bat 428 pollinated according to Safford, 2007), and such taxa are always under-represented in the 429 pollen rain. There are also relatively few wind-pollinated taxa in the ARF, but a number of 430 pioneer or secondary forest taxa are anemophilous - examples include 431 Moraceae/Urticaceae, Cecropia, Trema, Celtis, and Alchornea - and their high levels of 432 pollen production, combined with the often up-slope nature of mountain winds, lead to 433 over-representation of these montane taxa in many higher elevation pollen rain studies in 434 the neotropics (e.g. Weng et al., 2004; Niemann et al., 2010; Urrego et al., 2011; Montade et 
435 al., 2019). The relative paucity of CDA pollen in the lower elevation forest traps is driven 436 probably by the combination of predominantly upslope winds with the very high local 437 production of pollen in ARF, which masks the downslope movement of CDA pollen (see also 438 Bush, 2000; Schüler et al., 2014).

439 Another important difference between the CDA and ARF pollen assemblages is the size of 440 the pollen source area. Pollen samples from open areas dominated by Poaceae and subject 441 to high influence of wind transport will necessarily represent larger geographic areas than 442 samples from close canopy forests, where local pollen production strongly dominates 443 (Tauber, 1967; Schüler et al., 2014). This explains why, although our ARF traps were found 444 mostly in forest patches surrounded by CDA vegetation (almost 64\% of vegetation within $445100 \mathrm{~m}$ of the ARF traps was CDA), they still recorded an average of $>80 \%$ ARF pollen (Table 446 2). In some cases, forest pollen rain can be strongly influenced by individual trees beneath 447 which the traps are located (Cheng et al., 2020; Niemann et al., 2010; Weng et al., 2004). 448 One obvious case in our study is sample SOPT6, which registered $>70 \%$ Melastomataceae 449 pollen, while the adjacent sample SOPT5 (only $10 \mathrm{~m}$ distant) registered only $3 \%$ of this pollen 450 type.

451 A few unexpected results are worth briefly mentioning. The low percentages of Celtis and 452 Trema pollen in the lower montane sample SOPT21 - which are typically characteristic of 453 lower montane ARF - are anomalous and may represent masking by Melastomataceae. 454 SOPT21 also recorded a high percentage of Weinmannia which, although it produces large 455 amounts of pollen and is usually overrepresented in upper montane environments, is not normally present in lower elevation forest samples. In an arboreal floristic inventory of a 457 montane forest in the PARNASO, Pardo et al. (2007) registered the occurrence of all the 458 arboreal taxa we found in the pollen rain, except for Weinmannia. Cárdenas et al. (2019), 459 studying the modern pollen-vegetation relationship in Araucaria forest in southern Brazil 460 also remarked that although Weinmannia is normally cited as evidence of Araucaria forest, it 461 is much more floristically important at higher elevations.

462 In order to develop a reasonably accurate process by which fossil pollen records might be 463 used to better discriminate between grassland and forest habitats in such a complex 464 environmental mosaic, we proposed a suite of distinctive upper montane ARF taxa 465 composed of Weinmannia, Myrsine, Clethra, and Myrtaceae.

466 Calculated with more specific taxa than the pollen groups usually used to distinguish forest 
467 from CDA, this discrimination group excludes over-represented taxa (e.g. Celtis, Cecropia, 468 Moraceae/Urticaceae as observed in the pollen traps) as well as under-represented taxa 469 (e.g. Lauraceae in fossil samples). Within vegetation cover buffer at $50 \mathrm{~m}$ of the sampling 470 site, it reflects better proportion of forest cover (Fig. 5c). We believe this group is more 471 appropriate to discriminate vegetation change between forest habitats and CDA and can be 472 applied to fossil pollen data in order to support palaeo records interpretation. However, as 473 each region presents a different species occurrence pattern, its replication should be treated 474 with caution. It can be transferred to historical pollen data for the given region or other CDA 475 and forest mosaic in similar altitude and in the same mountain range in southeastern Brazil.

476 Moreover, data from a sediment core and a pollen trap from the same vegetation type may 477 lead to slightly different results with regard to pollen diversity (Jantz et al., 2013) as the 478 catchment area from which samples are taken may be different. For example, fossil samples 479 from lake sediments represent a large source area and high proportions of Poaceae and 480 Cyperaceae (Gosling et al., 2009). Sediments collect in the mosaic of CDA and forest in the 481 Highlands from southeastern Brazil are basically peats but also bogs, within a more local 482 catchment area (but probably also larger than the pollen trap source area) and the 483 contribution of these taxa are quite well representative of local diversity. Application of our 484 restricted ARF might be therefore more relevant for sites with local catchment area (e.g. 485 peats and bogs) than for site with large source area (e.g. lakes). Other point to consider is 486 that our study was based on 1 year of pollen rain, and probably there is variability in pollen 487 productivity according to changes in climatic conditions through the years. A long-term 488 investigation with pollen traps could be interesting to verify this possible variation.

\section{6. Conclusion}

491 Our study of the modern pollen rain along an elevational gradient was focused on 492 supporting palaeo-studies of vegetation and climate dynamics in southeastern Brazil by 493 helping to refine the pollen taxa and spectra that most robustly differentiate CDA and forest 494 habitats. Our assemblages indicated that vegetation distribution is closed related with 495 altitude, even with occurrence of low montane taxa in higher elevations. Although arboreal 496 taxa dominated all of our pollen assemblages, pollen traps located in CDA captured a 497 characteristic mix of grass, herbs, and shrub pollen. The results indicate that the CDA pollen 498 spectra represent much larger geographic areas than forest pollen spectra, which sample 
499 local taxa more heavily. Nonetheless, the pollen assemblages accurately reflected the

500 vegetation zone in which they were found, and we were able to specify a characteristic

501 group of taxa for each elevation. Our results underlined that special care must be taken with

502 pollen trap location, as samples can be strongly influenced by a few individual plants if they

503 dominate the trap area. Pioneer tree and liana species with anemophilous pollen disperal

504 dispersion produce copious pollen and were over-represented in CDA pollen traps from

505 higher elevation, these included Melastomataceae, Moraceae/Urticaceae, Cecropia, Trema,

506 and Celtis. As found in other tropical montane studies as well, the main direction of wind-

507 driven pollen dispersal seems to be uphill in our study area, although the low presence of

508 CDA pollen in lower elevation forest traps is probably also influenced by masking due to high

509 local pollen production in the study area forests. Finally, we proposed the use of a suite of

510 distinctive taxa which more confidently differentiate CDA and forest habitats from pollen

511 data. We believe that will prove useful to efforts to reconstruct and model climate and

512 vegetation dynamics in such kind of specific environment, with important applications to

513 conservation and management (e.g., developing the natural range of variation of CDA vs.

514 forest areas as a function of landscape and climate) and climate and vegetation science (e.g.,

515 developing a more quantitative idea of the dependence of CDA vegetation on climate

516 variability vs. natural disturbances like fire).

518 7. Acknowledgements

519 We gratefully acknowledge the ICMBio - Instituto Chico Mendes de Conservação da

520 Biodiversidade, original institution of the first author and for given permission to develop

521 this research in the PARNASO. We are especially thankful to Cecilia Cronemberger from

522 PARNASO and our guide Frederico Pimentel for helping in fieldwork. We cannot forget to

523 acknowledge the members of the Brazilian excursion from the University of Goettingen in

5242015 that helped to install the traps and photographed the fieldwork. This work was

525 supported by the Ciências sem Fronteiras/CNPq program, Brazil (grant no 232876/2014-2)

526 given to the first author.

$528 \quad 8 . \quad$ References

529 Aximoff, I., 2011. O que perdemos com a passagem do fogo pelos campos de altitude do $530 \quad$ Estado do Rio de Janeiro? Biodiversidade Brasileira 1(2), 180-200. 
531 Bartlein, P.J., Harrison, S.P., Brewer, S. et al., 2011. Pollen-based continental climate reconstructions at 6 and 21 ka: A global synthesis. Climate Dynamics 37(3-4), 775-802.

533 Behling, H., 1993. Untersuchungen zur spätpleistozänen und holozänen Vegetations- und Klimageschichte der tropischen Küstenwälder und der Araukarienwälder in Santa Catarina (Südbrasilien). Dissertationes Botanicae 206, J. Cramer, Berlin Stuttgart, 149pp.

Behling, H., 1995. Investigations into the Late Pleistocene and Holocene history of vegetation and climate in Santa Catarina (S Brazil). Veg. Hist. Archaeobot. 4, 127-152.

Behling, H., 1997a. Late Quaternary vegetation, climate and fire history from the tropical mountain region of Morro de Itapeva, SE Brazil. Palaeogeogr. Palaeoclimatol. Palaeoecol. 129, 407-422.

Behling, H., 1997b. Late Quaternary vegetation, climate and fire history of the Araucaria forest and campos region from Serra dos Campos Gerais, Paraná State (South Brazil). Review of Palaeobotany and Palynology 97, 109-121.

Behling, H., 2007. Late quaternary vegetation, fire and climate dynamics of Serra do Araçatuba in the Atlantic coastal mountains of Paraná State, southern Brazil. Vegetation History and Archaeobotany 16, 77-85.

Behling, H., Cohen, M.C.L., Lara, R.J., 2001. Studies on Holocene mangrove ecosystem

Behling, H., Dupont, L., Safford, H.D., Wefer, G., 2007. Late Quaternary vegetation and climate dynamics in the Serra da Bocaina, southeastern Brazil. Quaternary International 161, 22-31.

Behling, H., Safford, H.D., 2010. Late-glacial and Holocene vegetation, climate and fire dynamics in the Serra dos Órgãos, Rio de Janeiro State, southeastern Brazil. Global Change Biology 16, 1661-1671.

Bush, M.B., 2000. Deriving response matrices from Central American modern pollen rain. Quaternary Research 54, 132-143.

Bush, M.B., Weng, C., 2006. Introducing a new (freeware) tool for palynology. J. Biogeogr.

560 Cárdenas, M.L., Gosling, W.D., Pennington, R.T., Poole, I., Sherlock, S.C., Mothes, P., 2014.

561 Forests of the tropical eastern Andean flank during the middle Pleistocene. Palaeogeogr. Palaeoclimatol. Palaeoecol. 393, 76-89. 
Cárdenas, M.L., Wilson, J.O., Schorn, L.A., Mayle, F.E>, Iriarte, J., 2019. A quantitative study of modern pollen-vegetation relationships in southern Brazil's Araucaria forest. Review of Palaeobotany and Palynology 265, 27-40.

Cheng, Z., Weng, C., Foong, S.W., Dai, L., 2020. A study on modern pollen rain and pollen morphology in the tropical western Malay Peninsula and its implications for palaeoenvironmental reconstructions in the Sunda region. Review of Palaeobotany and Palynology, https://doi.org/10.1016/j.revpalbo.2020.104236 - PALBO 104236 -preproof.

Dray, S., Dufour, A., 2007. The ade4 Package: Implementing the Duality Diagram for Ecologists. Journal of Statistical Software 22 (4), 1-20.

Falkenberg, D.B., Voltolini, J.C., 1995. The Montane Cloud Forest in Southern Brazil. In: Hamilton, L.S., Juvik, J.O., Scatena, F.N. (eds.) Tropical Montane Cloud Forests. Ecological Studies 110, New York: Springer-Verlag, pp. 138-149.

Flora do Brasil 2020 under construction. Jardim Botânico do Rio de Janeiro. Available at: http://floradobrasil.jbrj.gov.br/

Fundação SOS Mata Atlântica/ INPE - Instituto Nacional de Pesquisas Espaciais, 2017. Atlas dos remanescentes florestais da Mata Atlântica - período 2015 - 2016. Relatório técnico. São Paulo.

Gomes, C.G., 2015. Composição florística e estrutural do componente arbóreo de um fragmento de mata nebular no Parque Nacional da Serra dos Órgãos, Rio de Janeiro, Brasil. Graduate dissertation, unpublished.

Gosling, W.D., Mayle, F.E., Tate, N.J., Killeen, T.J., 2009. Differentiation between Neotropical rainforest, dry forest, and savannah ecosystems by their modern pollen spectra and implications for the fossil pollen record. Review of Palaeobotany and Palynology 153, 75-85.

Hijmans, R.J., Cameron, S.E., Parra, J.L., Jones, P.G., Jarvis, A., 2005. Very high resolution interpolated climate surfaces for global land areas. International Journal of Climatology 25, 1965-1978. WorldClim - Global Climate Data, extracted in 8/05/2019.

ICMBio - Instituto Chico Mendes de Conservação da Biodiversidade, 2008. Plano de Manejo do Parque Nacional da Serra dos Órgãos. Available at http://www.icmbio.gov.br/portal/component/content/article?id=2196: parna-da-serrados-orgaos. 
Jantz, N., Homeier, J., León-Yánez, S., Moscoso, A., Behling, H., 2013. Trapping pollen in the tropics - Comparing modern pollen rain spectra of different pollen traps and surface samples across Andean vegetation zones. Review of Palaeobotany and Palynology 193, 57-69.

Jantz, N., Homeier, J., Behling, H., 2014. Representativeness of tree diversity in the modern pollen rain of Andean montane forests. Journal of Vegetation Science 25, 481-490.

Juggins, S., 2007. C2 User Guide: Software for Ecological and Palaeoecological Data Analysis and Visualization. University of Newcastle, Newcastle upon Tyne, UK.

Koehler, A., Galvão, F., Longhi, S.J., 2002. Floresta Ombrófila Densa Altomontana: aspectos florísticos e estruturais de diferentes trechos na Serra do Mar, PR. Ciência Florestal 12(2), 27-39.

Ledru, M.P., Rousseau, D.D., Cruz Jr., F.W., Riccomini, C., Karmann, I., Martin, L., 2005. Paleoclimate changes during the last 100,000 yr from a record in the Brazilian Atlantic rainforest region and interhemispheric comparison. Quaternary research 64, 444-450.

Lima, H. C., Geudes-Bruni, R.R. (eds), 1997. Serra de Macaé de Cima : Diversidade florística e conservação em Mata Atlântica. Jardim Botânico do Rio de Janeiro, Rio de Janeiro.

Machado Filho, L., Ribeiro, M.W., Gonzalez, S.R, Schenini, C.A., Santos Neto, A., Palmeira, R.C.B, Pires, J.L., Teixeira, W., Castro, H.E.F., 1983. Geologia. In: Projeto Radambrasil. Folhas SF. 23/24, Rio de Janeiro/ Vitória. Levantamento de recursos naturais, v. 32. Ministério das Minas e Energia, Rio de Janeiro. pp. 27-304.

Markgraf, V., Webb, R.S., Anderson, K.H. et al., 2002. Modern pollen/ climate calibration for southern South America. Palaeogeography, Palaeoclimatology, Palaeoecology 181(4), 375-397.

Martinelli, G., Bandeira, J., 1989. Campos de altitude. Editora Index, Rio de Janeiro.

Melhem, T.S., Cruz-Barros, M.A.V, Côrrea, A.M.S., Makino-Watanabe, H., Silvestre-Capellato, M.S.F., Esteves, V.L.G., 2003. Variabilidade Polínica em Plantas de Campos do Jordão (São Paulo, Brasil). Boletim do Instituto de Botânica de São Paulo, São Paulo.

Montade, V., Diogo, I.J.S., Bremond, L. et al., 2016. Pollen-based characterization of montane forest types in north-eastern Brazil. Review of Palaeobotany and Palynology $234,147-158$.

Montade, V., Ledru, M.P., Giesecke, T., Flantua, S.G.A., Behling, H., Peyron, O., 2019. A new modern pollen dataset describing the Brazilian Atlantic Forest. The Holocene, 1-10. 
Myers, N., Mittermeier, R.A., Mittermeier, C.G., Fonseca, G.A.B., Kent, J., 2000. Biodiversity hotspots for conservation priorities. Nature 403, 853-858.

Niemann, H., Brunschön, C., Behling, H., 2010. Vegetation/ modern pollen rain relationship along an altitudinal transect between 1920 and 3185 m a.s.I. in the Podocarpus National Park region, southeastern Ecuadorian Andes. Review of Palaeobotany and Palynology $159,69-80$.

Nimer, E., 1977. Clima. In: IBGE - Instituto Brasileiro de Geografia e Estatística. Geografia do Brasil: região sudeste, 3. IBGE, Rio de Janeiro, pp. 51-90.

Oksanen, J., Blanchet, F.G., Friendly, M., Kindt, R., Legendre, P., McGlinn, D., Minchin, P.R., O'Hara, R.B., Simpson, G.L., Solymos, P., Stevens, M.H.H., Szoecs, E., Wagner, H., 2019. Vegan: Community Ecology Package. R package version 2.5-5. https://CRAN.Rproject.org/package=vegan .

Pardo, C.S., Terra, G., Neri, A.C.A., Matos, D.M.S., 2007. Florística do componente arbóreo de um trecho de floresta do Parque Nacional da Serra dos Órgãos, Teresópolis, RJ. Revista Brasileira de Biociências 5(2), 792-794.

Portes, M.C.G.O., Galvão, F., Koehler, A., 2001. Caracterização florística e estrutural de uma Floresta Ombrófila Densa Altomontana do morro Anhangava, Quatro Barras, PR. Revista Floresta 31(1/ 2), 22-31.

Portes, M.C.G.O., Safford, H., Behling, H., 2018. Humans and climate as designers of the landscape in Serra da Bocaina National Park, southeastern Brazil, over the last seven centuries. Anthropocene 24, 61-71.

Prentice, C., 1988. Records of vegetation in time and space: the principles of pollen analysis. In: Vegetation history (pp. 17-42). Springer, Dordrecht.

QGIS Developing Team, 2019. QGIS Geographic Information System. Open Source Geospatial Foundation Project. http://qgis.osgeo.org.

Raczka, M.F., de Oliveira, P.E., Bush, M., Mcmichael, C.H., 2013. Two paleoecological histories spanning the period of human settlement in southeastern Brazil. Journal od Quaternary Science 28, 144-151.

Ribeiro, M.C., Metzger, J.P., Martensen, A.C., Ponzoni, F.J., Hirota, M.M., 2009. The Brazilian Atlantic Forest: How much is left, and how is the remaining forest distributed? Implications for conservation. Biological Conservation 142, 1141-1153.

Riccomini, C., Peloggia, A.U., Saloni, J.C.L., Kohnke, M.W., Figueira, R.M., 1989. Neotectonic 

activity in the Serra do Mar rift system (southeastern Brazil). Journal of South American Earth Science 2, 191-198.

Rodrigues, J.M., Behling, H., Giesecke, T., 2016. Differentiating vegetation types from eastern South American ecosystems based on modern and subfossil pollen samples: evaluating modern analogues. Veget. Hist. Archaeobot. 25, 387-403.

RStudio Team, 2016. RStudio: Integrated Development for R. RStudio, Inc., Boston, MA url: http://www.rstudio.com/.

Safford, H.D., 1999a. Brazilian Páramos I. An introduction to the physical environment and vegetation of the campos de altitude. Journal of Biogeography 26, 693-712.

Safford, H.D., 1999b. Brazilian Páramos II. Macro- and mesoclimate of the campos de altitude and affinities with high mountain climates of the tropical Andes and Costa Rica. Journal of Biogeography 26, 713-737.

Safford, H.D., 2001. Brazilian Páramos III. Patterns and rates of postfire regeneration in the campos de altitude. Biotropica 33, 282-302.

Safford, H.D., 2007. Brazilian Páramos IV. Phytogeography of the campos de altitude. Journal of Biogeography 34, 1701-1722.

Safford, H.D., Martinelli, G., 2000. Southeast Brazil. In: Inselbergs: Biotic diversity of isolated rock outcrops in tropical and temperate regions (ed. by W. Barthlott and S. Porembski). Ecological Studies $N^{0}$ 146. Springer-Verlag, Berlin. pp. 339-389.

Scheel-Ybert, R., 2001. Man and Vegetation in Southeastern Brazil during the Late Holocene. Journal of Archaeological Science 28, 471-480.

Scheer, M.B., Mocochinski, A.Y., 2009. Florística vascular da Floresta Ombrófila Densa Altomontana de quatro serras no Paraná. Biota Neotrop. 9(2), 51-69.

Schüler, L., Hemp, A., Behling, H., 2014. Relationship between vegetation and modern pollen-rain along an elevational gradient on Kilimanjaro, Tanzania. The Holocene 24, 702-713.

Spehn, E.M., Rudmann-Maurer, K., Körner, C., Maselli, D. (eds.), 2010. Mountain Biodiversity and Global Change. GMBA-DIVERSITAS, Basel.

Tauber, H. 1967. Investigations of the mode of pollen transfer in forested areas. Review of Palaeobotany and Palynology 3, 277-286.

Tonello, M.S., Mancini, M.V., Seppä, H., 2009. Quantitative reconstruction of Holocene precipitation changes in southern Patagonia. Quaternary Research 72(3), 410-420. 
691 Urrego, D.H., Silman, M.R., Correa-Metrio, A., Bush, M.B., 2011. Pollen-vegetation 692 relationships along steep climatic gradients in western Amazonia. Journal of Vegetation 693 Science $22,795-806$.

694 Verissimo, P.N., Safford, H.D., Behling, H., 2012. Holocene vegetation and fire history of the 695 Serra do Caparaó, SE Brazil. The Holocene 22, 1243-1250.

696 Weng, C., Bush, M.B., Silman, M.R., 2004. An analysis of modern pollen rain on an elevational gradient in southern Peru. Journal of Tropical Ecology 20, 113-124.

698

\section{Supplementary Material}

700 List of taxa identified in the pollen rain.

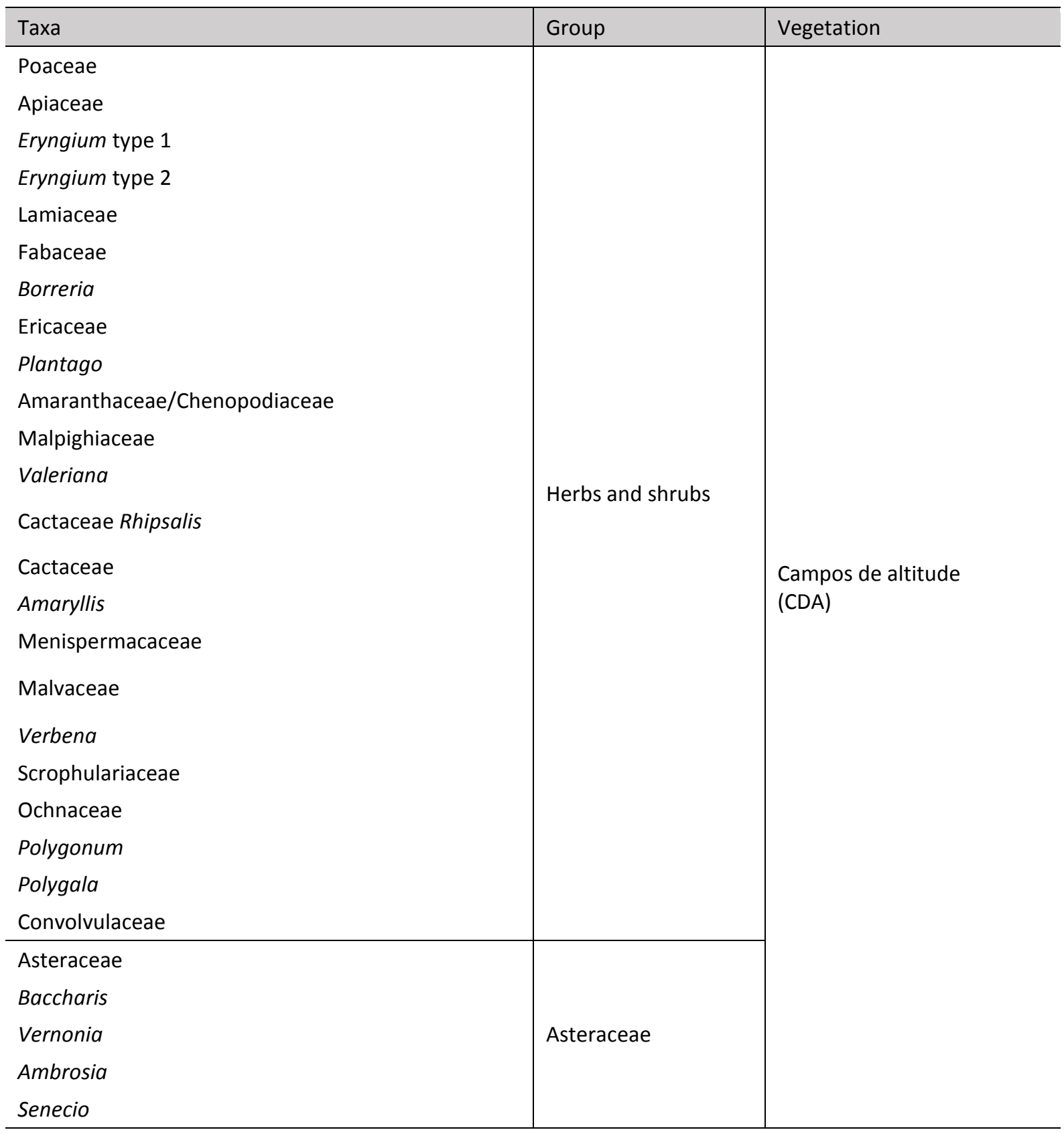




\begin{tabular}{|c|c|c|}
\hline Taxa & Group & Vegetation \\
\hline $\begin{array}{l}\text { Cyperaceae } \\
\text { Hydrocotyle } \\
\text { Xyris } \\
\text { Typha } \\
\text { Liliaceae }\end{array}$ & Sub-aquatics & Sub-aquatics \\
\hline $\begin{array}{l}\text { Clethra } \\
\text { Griselinia } \\
\text { Myrsine } \\
\text { Weinmannia } \\
\text { Symplocos tenuifolia type } \\
\text { Symplocos lanceolata type } \\
\text { Hedyosmum } \\
\text { Drimys } \\
\text { Daphnopsis } \\
\text { Croton } \\
\text { Roupala } \\
\text { Lauraceae } \\
\text { Lamanonia } \\
\text { Fuchsia } \\
\text { Begonia } \\
\text { Euphorbia } \\
\text { Laplacea } \\
\text { Struthanthus } \\
\text { Podocarpus } \\
\text { Araucaria } \\
\text { Mimosa scabrella } \\
\text { Melastomataceae } \\
\text { Melastomataceae (small) } \\
\text { Flacourtiaceae } \\
\text { Myrtaceae } \\
\text { Ilex }\end{array}$ & 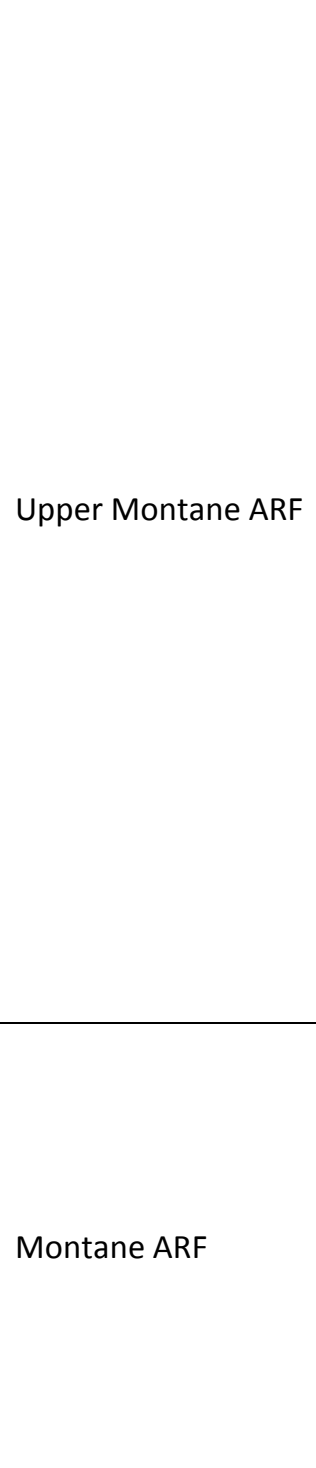 & Atlantic rain forest (ARF) \\
\hline Taxa & Group & Vegetation \\
\hline $\begin{array}{l}\text { Mimosaceae } \\
\text { Mimosa (small) } \\
\text { Schefflera } \\
\text { Oreopanax } \\
\text { Sebastiana commersoniana } \\
\text { Sebastiana brasiliensis } \\
\text { Piper } \\
\text { Trema } \\
\text { Celtis } \\
\text { Schinus }\end{array}$ & 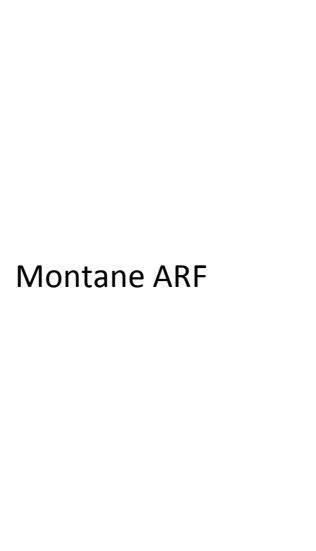 & Atlantic rain forest (ARF) \\
\hline
\end{tabular}


Zanthoxylum

Meliosma

Allophyllus

Luehea

Pera

Parapiptadenia

Matayba

Bignoniaceae

Anacardiacceae

Bauhinia

Cordia

Rubiaceae

Rubiaceae Bridelia

Lythraea

Dodonea

Solanaceae

Prunus type

Euterpe/Geonoma

Cecropia

Moraceae/Urticaceae

Alchornea

\begin{tabular}{|c|c|c|}
\hline Taxa & Group & Vegetation \\
\hline $\begin{array}{l}\text { Sloanea } \\
\text { Schizolobium } \\
\text { Rhamnus } \\
\text { Tetrorchiolium }\end{array}$ & Montane ARF & Atlantic rain forest (ARF) \\
\hline $\begin{array}{l}\text { Pinus } \\
\text { Casuarina }\end{array}$ & Exotics & Exotics \\
\hline $\begin{array}{l}\text { Cyathea psilate } \\
\text { Cyathea reticulate } \\
\text { Cyathea verrucate } \\
\text { Dicksonia } \\
\text { Lophosoria quadripinnata }\end{array}$ & Tree ferns & \\
\hline $\begin{array}{l}\text { Lycopodium foveolate } \\
\text { Lycopodium clavatum } \\
\text { Monolete psilate } \\
\text { Monolete psilate large (> } 40 \text { ?m) } \\
\text { Monolete scabrate } \\
\text { Monolete echinate } \\
\text { Monolete verrucate } \\
\text { Monolete verrucate large } \\
\text { Osmunda } \\
\text { Polypodiaceae } \\
\text { Monolete with perispore type } 2\end{array}$ & Ferns & Ferns \\
\hline
\end{tabular}


Pteris type

Schizaea

Trilete psilate

Trilete verrucate

Trilete scabrate

Pteridophyta type 6

Pteridophyta type 4

Trilete with perispore

Trilete striate

701

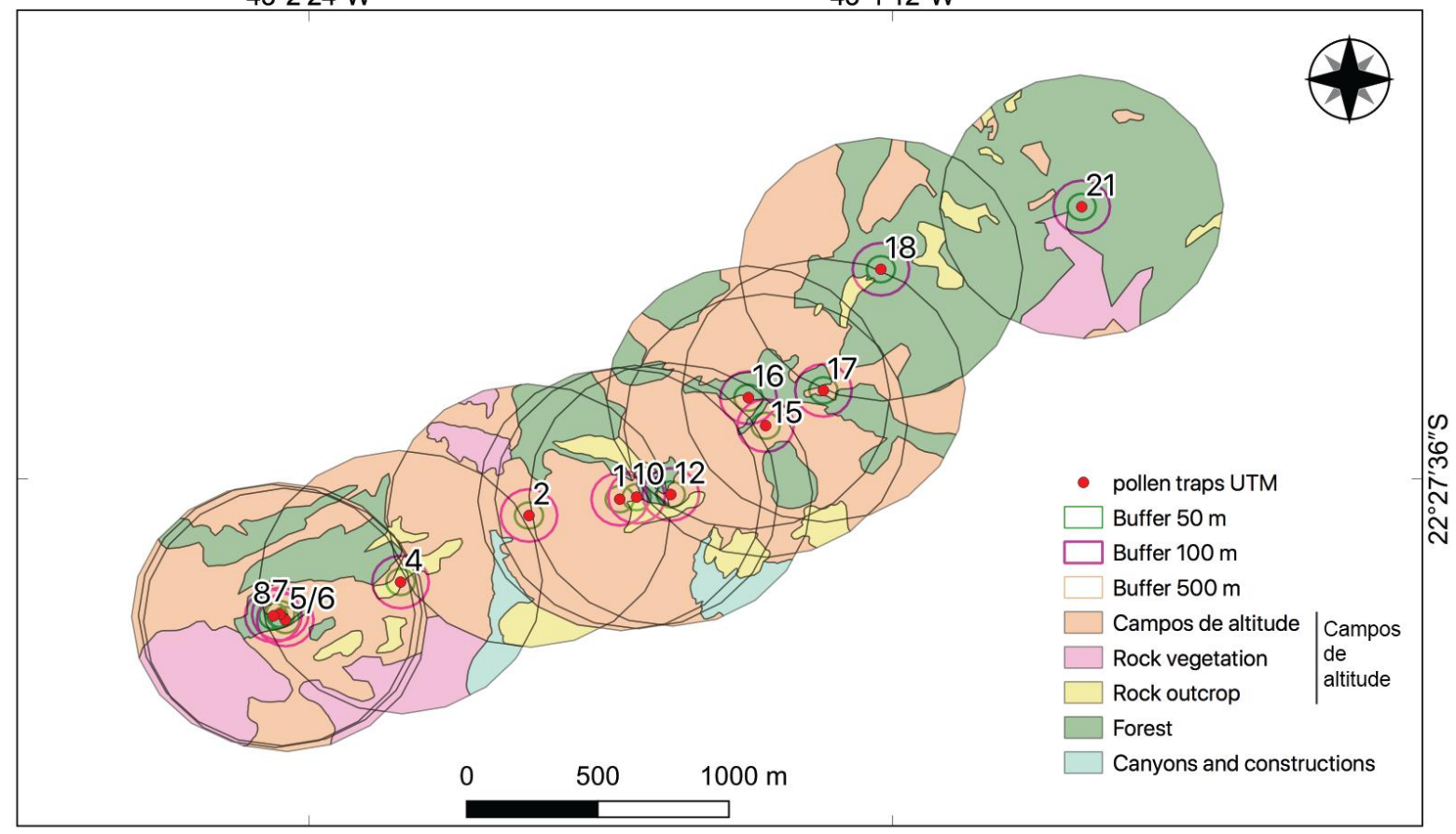

703 Figure S1: Interpretation of the vegetation surrounding each pollen trap and limit of the

704 spatial buffers of $50 \mathrm{~m}$ radius ( 0.79 ha total area), $100 \mathrm{~m}$ radius ( 3.14 ha total area) and 500 $705 \mathrm{~m}$ radius (78.6 ha total area). 

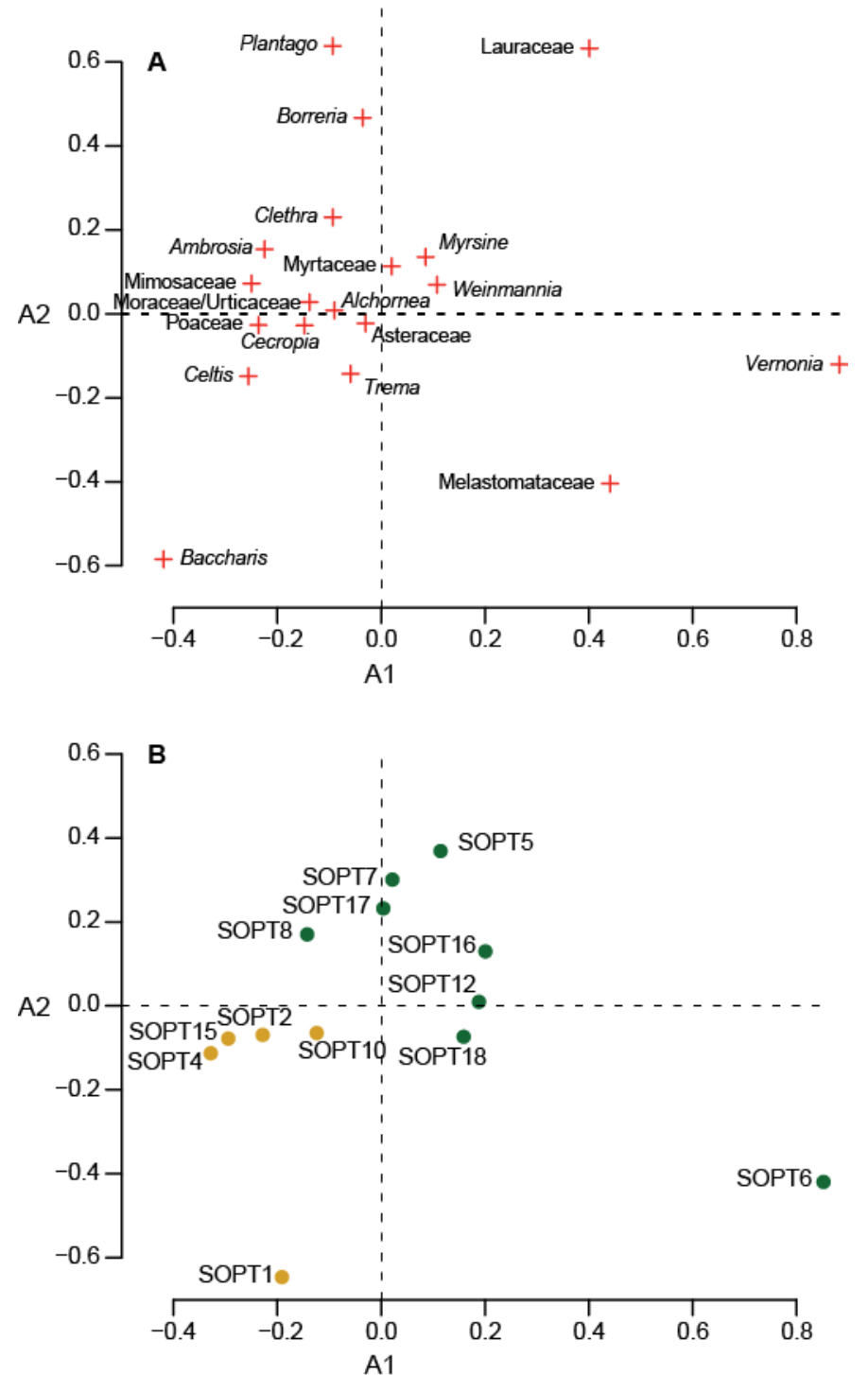

707 Figure S2: Correspondence Analysis (CA) for axes 1 and 2 using pollen taxa $>1 \%$ in at least 708 three samples, including sample SOPT6. A - distribution of pollen taxa, B - distribution of 709 pollen traps. 